\title{
The Brazilian Spring: Reconsidering Risk Assessment in Business and the Global Political Economy
}

\author{
Raul Gouvea (Corresponding author) \\ Professor of International Management \\ Anderson School of Management, University of New Mexico \\ E-mail: rauldg@unm.edu \\ Dimitri Kapelianis \\ Assistant Professor of Marketing \\ Anderson School of Management, University of New Mexico \\ E-mail:dkapeli@unm.edu \\ Manuel Montoya \\ Assistant Professor of International Management \\ Anderson School of Management, University of New Mexico \\ E-mail:mrmonto@unm.edu
}

Received: March 12, 2014 Accepted: March 24, 2014 Published: March 31, 2014

doi:10.5296/csbm.v1i1.5407

URL: http://dx.doi.org/10.5296/csbm.v1i1.5407

\begin{abstract}
In June of 2013, Brazil saw a massive outbreak of public protests and demonstrations. The government's apathy in responding to demands for greater transparency and enhanced levels of public services, as well as increasing levels of corruption and opacity, lead to these public uprisings. This paper argued that emerging economies with a growing middle class, particularly those that do not pay heed to this emerging class and their needs, are bound to face "spring-type" events. Utilizing a case study "quadruple helix" framework, this paper conducted an institutional analysis of the Brazilian "Spring" movement. This analysis yielded a considerable set of descriptions that can enhance the way that "spring-type" events influence business, policy, and economic behavior. More specifically, this research contributed an institutional approach to scholarship on risk analysis and geo-political unrest,
\end{abstract}




\section{Macrothink}

establishing new trajectories for future scholarship that places risk analysis in the context of international management and world political economy.

Keywords: Risk assessment, Global political economy, Economic sociology, Developing economies, Emerging markets 


\section{Introduction}

Public demonstrations have erupted around the globe, challenging and changing the traditional approach to a country's risk assessment. Several governments are under siege, pressured by an increasing public dissatisfaction with the substandard delivery of political, economic, and social assets.

In the past few years, the roots of public demonstrations have been very diverse across the globe. For instance, uprisings in Egypt, Turkey, Tunisia, Greece, United States, and Brazil, have emerged as a result of various situations such as: economic crisis, high unemployment rates, authoritarian and opaque political regimes, lack of basic good quality public services, and corruption. These have all led to different shades of "Spring" types of public movements in many countries across the world (Jamshidi, 2013; Fernandes et al., 2013; Lynch, 2013; The Economist, 2013a).

The results of these demonstrations have also had diverse political, economic and social outcomes. For instance, in some authoritarian regimes such as Egypt and Tunisia we saw the emergence of new political forces, and the toppling of the established government (Anderson, 2011; Guzzi, 2010; Hamid, 2011; Naim, 2013).

Conflicts and different perceptions of the dynamics and interactions between the populace and political leaders and governments have been the object of many observers and scholars over the past few centuries and are again at the core of current global "Spring" movements (Bodin, 1955; Bobbio, 1987, 1996; Castells, 2012; De La Boetie, 1997; Guicciardini, 1994; Hotman, 2010; Cortes, 2008; Vespa, 2012; Yavetz, 1988).

More than ever the dynamics and interactions between governments, civil society, political apparatus, NGOs, and social media are shaping the way governments and populaces interact and express their expectations and demands (Borges, 2013; Buscato, 2013; Cardoso, 2013; Delfim Netto, a, b; Faustini, 2013). Figure 1 showcases the main actors involved in a number of "Springs" around the globe. It is clear that civil societies are more sophisticated and more willing to express their expectations and demands. NGOs and social media have been at the forefront of these "Spring" movements by offering new channels for civil societies to express their aspirations. Governments have been moving at analog speeds in many of the "Spring" movements and as a result, some have seen dramatic implications because of their slow, reluctant reactions to their populace demands. A nation's political system and its corresponding apparatus should be the main channel for the expression of their population demands and aspirations. New political forces are also being created in a number of the countries experiencing "Spring" movements (Franco, 2013; Giannetti da Fonseca, 2013; Gielow, 2013; Kahne, Lee, and Feezell, 2013; Martins, 2013). 


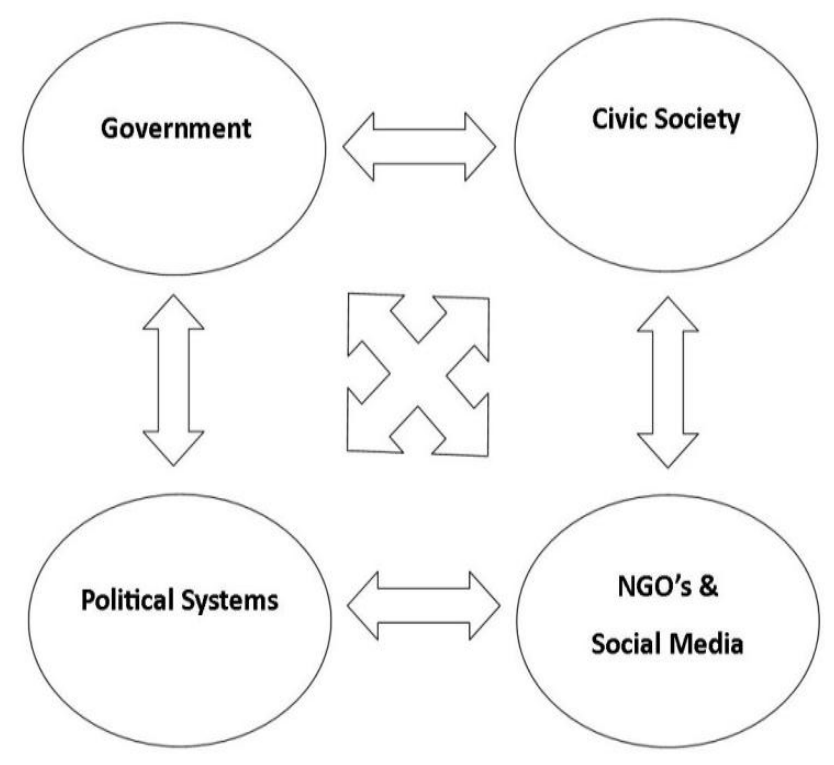

Figure 1. The Quadruple Helix “Spring” Model

Source: elaborated by the authors.

The lack of transparency in governments' policies and actions has recently created a global tide of public protest and resistance. Moreover, the arbitrary characteristic of several governments, are fueling these massive demonstrations (Della Porta and Rutcht, 2013; Naim, 2013; Ortellado, 2010).

These countries that are characterized by different shades of democracy have not fully understood the full implications of transparency in democratic regimes. They are still operating under the assumption that there is no need for full disclosure. For instance, in several countries taxpayers are questioning the allocation and disbursement of taxes, mainly in countries that show a very high tax to GDP ratio and poor quality of public services. The lack of accountability by governments is at the root of several of these global demonstrations.

The transparency and pervasiveness of the internet does not find a parallel in many of these government's procedures and responses, it has been able to amplify the press, radio, and television media (Rheingold, 2002; 2012). Social networks have been used worldwide during the demonstrations: Face Book, Twitter, YouTube, Instagram, Tumblr, and Watsapp (Papp and Rocha, 2013). Lacking traditional channels of communication between populace and governments, the social media has been conveying the sentiments and demands of the populace and has also been used as a conduit to organize public demonstrations and pressure governments (Castells, 2012; Juris, 2005; 2008). More than ever monitoring and following of social media has become the new paradigm for country risk assessment. In the age of hyper connectivity governments are moving at an analog speed while societies across the globe are moving at digital speeds (Kramer, 2013). The internet is fundamentally changing the nature of the relationships between populace and governments, and fundamentally challenging 
traditional approaches to country risk assessment (Oliveira, 2013).

It is not necessary or sufficient for demonstrations to occur only when the basic needs of a population are not being met (Canetti, 1984; Caplan, 2008, Roche, 2006). Recently, theories such as the "Political Opportunity" add to the realm of resource mobilization by not only emphasizing resources but also the political environment; it is also an advancement over the theory of entrepreneurial mobilization (Meyer and Minkoff, 2004; McVeigh, Neblett, and Shafiq, 2006). The theory of "Political Opportunity" and the theory of resource mobilization also state that dissatisfaction is an important feature but not the sufficient reason to protest. (Jenkins, 1983; Meyer and Minkoff, 2004; Kahne, Lee, and Feezell, 2013)

\section{Brazil's "Spring"}

Contrary to the Arab "Spring", Brazil's "Spring" happened in a democratic environment, where the economic situation was relatively stable and the level of unemployment was low compared with Western European, and Arab nation's standards (Almeida, 2013; Amaral, 2013; Arantes, 2013; Lago and Orofino, 2013; Martins, 2013). The Brazilian "Spring" may be compared to the 1968 Parisian movements where Brazil, after one decade of relative economic growth and low levels of unemployment, saw itself plagued by political corruption, government inefficiency and lack of direction resulting in a certain "malaise" i.e., a disappointment of how the country was being managed and the direction the country was taking (Bacha, 2013; Machado and Rocha, 2013; Naude, 1988).

In 2013, Brazil was going through an inflection point; the "darling of foreign investors" saw itself under increasing scrutiny and criticism from within Brazil and from foreign investors. After a period of stable but low rates of economic growth, growing foreign trade, and inflow of substantial volumes of foreign direct investment (FDI), Brazil started to show mediocre levels of economic growth and development, revealing the inconsistencies and flaws of its populist government (Maia and Cruz, 2013; Ming, 2013; Martins and Machado, 2013).

This inflection point was the result of internal and external forces. On the domestic front, the lack of government efficiency coupled with high levels of taxes and corruption by government technocrats, politicians, and members of the government, resulted in the low quality of public services, which generated frustration amongst the Brazilian population.

On the external front, the slowdown in China's economic growth, coupled with a prolonged recession in Western Europe and the U.S. lead to lower levels of trade and foreign direct investment which deeply affected Brazil's economy. These external events translated into slower rates of economic growth and slower job creation. This "perfect storm" scenario created the right environment for massive public demonstrations in 2013 (Bonelli and Fontes, 2013; Paulino and Janoni, 2013; Salomao, 2013; The Economist, 2013).

After two decades, since the impeachment process against the first democratically elected president Fernando Collor de Mello, Brazil experienced massive public demonstrations around the country, sending shock waves throughout Brazil's society and political establishment (Papp and Rocha, 2013). In 2013, public demonstrations took place in 438 municipalities and all capitals of Brazilian states, including Brasilia (Manso and Burgarelli, 
2013). These public demonstrations were not manipulated and guided by political parties, such as the Collor impeachment movement, which was manipulated by the Labor Party (PT). These public demonstrations were spontaneous, not linked to any political party nor labor unions.

Millions of people took to the streets all across Brazil, making other past street demonstrations pale in comparison. Brazil had seen massive public demonstrations in the 1960s such as the "Marcha pela Familia, pela Patria e pela Liberdade" and the "Passeata dos Cem Mil". But none of them compared to the millions of people demonstrating on the streets during the month of June 2013 (Borges, 2013; Cabral and Leitao, 2013; Castellar Pinheiro, 2013; Faria Mello, 2013; Machado, 2012).

These 2013 demonstrations were a direct result of the managerial and political incompetence demonstrated by Lula's and Dilma's administrations in managing and allocating public resources towards providing Brazilians with good quality public services along with Brazil's global economic rankings (Mendonca de Barros, 2013). In addition the levels of corruption never seen in Brazil's recent history further compromised the government's standing with Brazil's population. Thus, excessive expenditures on the 2014 World Cup offered a counterpoint to the low quality of urban mobile transportation systems, health care system, and public schools. Along with the strong insecurity felt by the Brazilian population in face of rising criminality in the rural and urban environments, this compelled the population to show their dissatisfaction on the streets (Fraga and Carneiro, 2013; Franco, 2013; Goncalves, 2013; Guzzo, 2013).

The period between 2003 and 2013 also saw the increasing deterioration of political channels and the increasing co-optation of social movements and labor unions by the Labor Party (PT). Entities such as Brazil's National Student Association (UNE) that had been historically important in voicing Brazil's student's political concerns were put on the government's payroll by Lula's administration. Labor unions were also co-opted by the Lula and Dilma's administrations. This co-option of opposing political parties and social movements resulted in the isolation of the government from the streets and from emerging political and social movements. Thus, the Lula and Dilma government's lost their ability to read the Brazilian "streets" and their ability to effectively assess Brazil's political and social risk (Oliveira, 2013; Pereira, a,b,c; Rabelo, 2013) .

In addition, the increasing co-option of politicians by the Lula and Dilma administrations, culminated among other impacts on the "Mensalao", i.e., when the Lula government bought politicians votes in return for their political support, using public funds. So the lack of substantial political dialogue and the weakening of the political dialogue in the two houses of Congress, further explain the disappointment of Brazil's population and its frustration with the Dilma government, and with politicians in general. The widening gap between campaign promises and elected officials' actions has become increasingly visible, further increasing the frustration of the Brazilian populace. Once elected, politicians abandon their electoral promises in favor of political arrangements and self-driven actions.

The demonstrations were a clear indication that Brazilian political channels were no longer 
representative of the population demands. The government failed in creating an environment to foster the processing of these aspirations and demands (Carta, 2013; Ribeiro, 2013; Romano, 2013a, b; Sakate and Daltro, 2013).

One of the hallmarks of Brazil's "Spring" has been its refusal to connect and identify itself to established political parties, sending a clear message that these political parties are no longer representing their aspirations and demands. The Brazilian political parties have not been effective in carrying the message and transforming it into government actions and programs (Borges, 2013).

Moreover, the lack of established political leaders' reaction to the massive public demonstrations, such as the former president Lula, aggravated the population's perception that the Labor Party had lost its grip and control of public demonstrations. Lula's disappearance during the Brazilian "Spring" further compromised his successor's ability to manage the political uprising. It is very clear that Lula's legacy is largely responsible for the nation's state of affairs and the massive demonstrations. His decision not to voice his opinion or even to write or talk about the demonstrations revealed his increasingly weaker leadership in Brazil's domestic affairs. President Dilma Rousseff, only addressed the nation 15 days after the first public demonstration, showing her lack of understanding and capacity to answer and address Brazil's society demands. President Dilma showed a complete lack of preparedness by her government to deal with the population increasingly questioning her government (Bernabucci, 2013; Bonin and Cabral, 2013; Cabral, 2013a, b).

The Edelman Trust Barometer 2013 showcased the dramatic reduction in Brazilians' trust in their political leaders. Between 2011and 2013, Brazil saw a reduction from 80 to 55 points, out of a possible 100 points. These dramatic results showcased Brazilians distrust in its political system, the abilities of leadership, and in its government (Edelman, 2013). Corruption, poor performance and incompetence, and transparency issues are at the core of the large majority of complaints (Rossi, 2013). In addition, Dilma had a very low support amongst Brazilian young population 16-34 years old (Paulino and Janoni, 2013).

The Brazilian "Spring" also showcased that the Labor Party (PT) is no longer the party of transformation in Brazil. The Labor Party has lost its "clout" within the Brazilian population's social and political "channels." The "pure and corruption fighter political party" has been severely damaged by the lack of managerial competence by its political leaders and the increasing corruption permeating its members. In addition, as a result of co-opting social movements that could have provided the government with a "street support barometer" they have lost their ability to understand and to formulate policies and programs to address the population's demands, resulting in its irrelevance and capacity to address social issues and demands (Oliveira, 2013).

Many political parties have not realized that Brazil's society has gone through major transformations since the early 1990s (Chaui, 2013; Belluzo, 2013; Neri, 2012; Reis Velloso, 2013). It has become more politicized, more educated, and more informed. In this period, Brazil's political system and government were not able to reinvent themselves. As a result there is a growing gap and incompatibility between the population's aspirations and the 
archaic political system of the government that have a power project, not a government project, much less a state project for Brazil.

\section{Brazil's Spring: “Raison D'Etre”}

The massive public demonstrations during 2013 raised a number of issues about Brazil's social, economic, and political stability. The structural roots of Brazil's "Spring" movement can be traced to the lack of political leadership, vision, lack of efficient governance, and a growing institutional crisis. The "Spring" movement was a result of years of structural imbalances that permeates the Brazilian economy, society, and political system (Goncalves, 2013). This section will address the main issues that prompted the 2013 Brazilian Spring movement.

\subsection{Corruption}

In 2012, Transparency International ranked Brazil $69^{\text {th }}$ out of 174 countries, showcasing the extent of corruption permeating Brazil's economy (www.transparency.org). It is estimated that in 2012 corruption schemes were equivalent to 2\% of Brazil's GDP, or close to US\$ 41 billion. This has been the one common thread between all public demonstrations in Brazil. After the demonstrations, the Brazilian Congress stepped up a number of measures to further penalize lawbreakers, making corruption charges stricter and also making not only companies' staff responsible, but the company itself liable in cases of corruption. These reforms were waiting in Congress for many years (Cruz, 2013; FIESP, 2010; Pereira, 2013c; Pilagallo, 2013).

One of Brazil's corruption dimensions is the long corruption trials delay. Currently there are close to 250,000 actions against people that have committed crimes against Brazil's public administration, but only 1,100 are ruled per year. The slow pace of Brazil's justice system penalizes Brazil's society and economy. It takes ten times longer in Brazil than in the US to rule on charges of corruption (Cruz, 2013; Gama, 2013).

Before the elections of 2002, the Labor Party (PT) commanded the political leadership on ethical and social issues (Ribeiro, 2013). The PT was born as the ethical party. i.e., that was PT's main calling card. Since the 2002 elections, however, the PT has lost its ethical vein. Ethics no longer function as the party's compass, since the Labor Party of ideals, turned into the Labor Party of deals. Lula, PT's first elected president, established a "coalition party" strategy to govern the country, striking political deals with different parties in order to co-opt their support and alliance (Gouvea, Montoya, and Walsh, 2013; Ribeiro, 2013). For instance, the number of ministries expanded dramatically during Lula's tenure in power 2003-2010, accommodating political parties' demands for more visibility and access to public resources. The low level of articulation and great independence has created the multiplication of functions, redundancies, and the waste of public resources (Romano, 2013b; Sundfeld, 2013).

Thus, the Labor Party represents the "old" Brazilian ways of doing politics as exemplified by the "Mensalao embroglio". The Labor Party thus has perpetuated Brazil's old political system. Brazil's society has matured and has evolved, but its political parties such as the Labor Party have not evolved. Brazilian political parties have been incapable of providing new and 
alternative political software. The lack of transparency, the opulence of mayors, governors, technocrats, and politicians has shocked the Brazilian society. The "palace of government favelas" dichotomy is no longer accepted by Brazilians (Kramer, 2013; Pereira, 2013a, b).

\subsection{World Cup}

The high cost of hosting the 2014 World Cup was one of the factors prompting public demonstrations in 2013 since a number of public services were suffering and underfunded. In 2007, Lula announced that the bulk of investments to prepare Brazil to host the 2014 Soccer Cup would come from Brazil's private sector. However, the opposite happened, the Brazilian government provided the larger share of the bill, upsetting Brazilians (Bernabucci, 2013; Cabral and Leitao, 2013).

The Brazilian government is funding close to $80 \%$ of all expenditures for the World Cup in 2014. In 2007, the Minister of Sports stated that there would be no resources coming from the federal government to finance the 2014 World Cup. In 2007, Lula's government estimated that US $\$ 3.5$ billion would be needed to build and revamp soccer stadiums and that the larger share of funding would come from the private sector. However, by 2013 only US\$ 306 million had been sourced from the private sector (Salvador et al., 2013).

It became clear to protesters that the Lula and Dilma administrations had the resources to build stadiums, but made a political decision not to channel similar amounts of resources to Brazil's failing transportation system, health care, education, and security (Jungerfeld, 2013; Oricchio, 2013).

To make this situation even worse, the cost of Brazil's hosting the 2014 World Cup reached close to US\$ 14 billion. This is a much higher figure when compared to the cost of hosting by other nations in the past three World Cups combined. For instance, the 2002 and 2006 tournament cost US\$ 5 billion, and close to US\$ 3.5 billion for the 2010 South African tournament. Thus, the Brazilian 2014 World Cup in terms of cost is equivalent to all three tournaments put together (Salvador et al., 2013).

The government so far has not been able to justify the astronomic cost of hosting the cup. Moreover, the population, seeing the disarray of Brazil's public services and the increase of crime, was outraged because of Lula-Dilma's actions to host the 2014 World Cup. The government initially promised that these expenditures would have positive spillover effects on the country's public services and other sectors.

\subsection{Education}

The 2013 OECD's report, "Education at a Glance", indicates that among 31 nations, Brazil was at the bottom when it came to students' expenditure per capita. It was close to US\$2,600, compared to OECD's average of US\$ 8,412 and the United States expenditures of US\$ 11, 859 per year. Brazil's educational standards as measured by OECD's 2012 "Education at a Glance" also indicates how poor Brazil's standards are in comparison to other countries in the reading, mathematics and science dimensions. Out of 65 countries, Brazil ranked $53^{\text {rd }}$, behind other BRIC countries such as China who was ranked in first place. In the era of a 
knowledge-driven global economy, this educational performance further penalizes Brazil's overall economic competitiveness and the welfare and aspirations of its society (OECD, 2013; Weber and Rodrigues, 2013).

This dismal performance has many dimensions. For instance, policy-makers are allocating five times more resources per student at the college level than it does at the k-12 level. In 2011, Brazil spent close to US\$2,000 per k-12 student compared to US\$10,000 at the college level (Fraga, 2013).

Brazil has 10,838 schools functioning in very poor conditions, the large majority in the North and Northeast regions. Only $0.6 \%$ of Brazilian schools have a library, labs, sports facilities and accommodations for people with disabilities. Also $44 \%$ do not go beyond the minimum such as having tap water, electric energy, bathrooms, and kitchen facilities. These very poor conditions have a direct impact on the quality of education and learning in Brazil (UNB, 2013). In 2013 Brazil still had close to 13 million Brazilians that could be classified as illiterate, and close to 30 million that could be classified as semi-illiterate (Pombo and Oliveira, 2013).

In 2013, Brazil's illiteracy rate increased to $8.7 \%$, reaching close to 13.2 million Brazilians, (Leal, 2013). The situation is again much worse in Brazil's Northeast region where one out of two Brazilians are illiterate. In the Northeast region, illiteracy rates are close to $17.4 \%$. Initially, the government had estimated that by 2015 literacy rates would be in the $6.7 \%$ range, or 3 million people. Once again the government has failed to deliver on its promises, only $15 \%$ of Brazilians in the age range to attend college are currently enrolled in universities (Ridenti, 2013). Brazil needs urgently to improve its educational infrastructure as well as improve the quality of its teachers, and create educational targets.

\subsection{Health Care}

The quality of Brazil's public health care system is very poor and was a major driver of the Brazilian "Spring" (Guimaraes and Pedroso, 2013). Long lines along with the low quality of services and infrastructure compounds and aggravates Brazil's Health component of UN's Human Development Index. In 2013, the United Nation's Human Development Report, ranked Brazil $85^{\text {th }}$ out of 186 countries in the health care dimension (UN, 2013). This is a very low ranking for a country whose economy is ranked amongst the top ten in the world.

In addition to the poor quality of Brazil's public health care system, the country also faces a regional health care divide when it comes to the allocation of medical doctors per capita. Brazil shows a very high concentration of medical doctors per capita in the wealthiest regions of Brazil such as the southeast, where the ratio is close to 2.67 MDs per one thousand people, compared to 1.01 MDs per one thousand in Brazil's north and 1.23 MDs per one thousand in the Northeast region. Brazil's average is close to 1.8 MDs per capita, compared to Germany's 3.6 MD per capita. Adding more stress to Brazil's health care coverage, close to $15 \%$ of Brazilian municipalities do not have MDs.

In 2011, Brazil spent close to US\$ 943 per capita on health care, compared to the United States US\$ 7,410, or US\$ 4,129 for the country of Germany. Thus, for an economy ranked $7^{\text {th }}$ 
in the world, Brazil spent very little on a per capita basis (WHO, 2011 - Global Health Observatory Data Repository, 2011). Out of every four newly graduated MDs in Brazil, only 1 will work in the public sector while the other 3 will work in private health care (Guimaraes and Pedroso, 2013).

In order to address the faulty and decayed public health care system, the Dilma government imported 6,000 foreign medical doctors, the large majority coming from Cuba. However, only $5 \%$ of Cuban MDs have been approved in the past by the Brazilian Ministry of Health. In addition, no measures were taken to take care of Brazil's health care hardware and software. The lack of good working conditions in Brazilian public hospitals led to the concentration of MDs in Brazil's wealthiest regions, such as the Southeast region. In addition, health care agencies such as Funasa were further strained by political appointees with no expertise in the field of health care. In addition, the allocation of federal resources to SUS was reduced from $17 \%$ to $14 \%$ of the Ministry of Health's overall budget (Serra, 2013; Estado de Minas, 2013).

\subsection{Transportation \& Urban Mobility}

The initial motivation for the Brazilian Spring was the increasing cost of urban mobility fares (Martins, 2013). The poor quality and high prices of Brazil's urban transportation systems, aggravated by a lack of urban mobility planning, deeply penalizes Brazilians using urban transportation (UN, 2012; Zaparolli, 2013). Since 2002 the bus fare rates in Brazil have increased well above rates of inflation despite the poor quality of urban mobility infrastructure (DiCunto, 2013). Moreover, in 13 state capitals, or 50\% of Brazilian capitals, there was not a public bidding system to run their urban transportation systems, leading to increasing inefficiency, high levels of opacity, and high prices of Brazil's urban transportation. As a result low income Brazilians spend on average 13\% of their monthly budgets on urban transportation and long hours commuting (Duarte and Benevides, 2013; Sposito, 2013). In $2013,44.7 \%$ of all Brazilian municipalities with a population over 500,000 did not have an urban mobility plan, establishing guidelines for their urban centers. If all Brazilian municipalities were taken into account, only $3.1 \%$ would show some form of urban mobility plan (Castro, 2013; IBGE, 2013). The segregation and the lack of efficient mobility around Brazil's urban centers penalize the low income residents who expend a much larger share of their income and time commuting around the city (Caldeira, 2012).

The addition of 30 million Brazilians to the low middle class also created a surge in demand for cars, strongly supported by the federal government, in detriment to investments in mass transportation. Additionally, the dramatic increase in the number of cars to Brazil's urban centers was not followed by efforts to mitigate, improve, and expand urban mobility (Fraga and Carneiro, 2013).

This state of affairs can be seen in a number of reports such as the "The Global Competitiveness Report" by the World Economic Forum and by the Ernest \& Young 2013 Infrastructure Report. According to the World Economic Forum Report in 2012 Brazil ranked $104^{\text {th }}$ out of 142 countries in quality of overall infrastructure. These results clearly indicate that Brazil has not paid attention to the importance and impact of the quality of its overall 
infrastructure on the country's economic and social competitiveness. The Ernst \& Young Report ranked Brazil in $107^{\text {th }}$ place in its assessment of Brazil's quality of urban transportation, telecommunications and energy infrastructure. It is very clear that the Lula-Dilma administrations have not understood the importance and role of an efficient urban transportation system to the cities' competitiveness and overall quality of life (World Economic Forum, 2013; Ernest \& Young, 2013).

\subsection{Security}

Recently, violence has become rampant in Brazil's urban centers and in its rural areas. Brazil shows a homicide rate of 27.4 per 100 thousand inhabitants, a rate that is 137 times higher than a country like Japan or England, which makes Brazil the $7^{\text {th }}$ most violent country in the world. The situation is even worse when teenager homicide rates are taken into account, which doubles the homicide rate to 54.8 (Cebela, 2013). The increasing sense of insecurity in Brazil's cities was also a major factor driving the "Spring" demonstrations. According to recent estimates, violence costs the country close to 5\% of its GDP annually. These numbers do not take into account the stress on Brazil's social fabric (IPEA, 2012).

\section{Institutional Analysis}

The Pew Research Center in its 2013 survey of Brazil showed that the Brazilian population is very skeptical about the future, and is not satisfied with the Brazilian government performance (Pew Research Center, 2013). Abraham Lincoln once said, "You can fool all the people some of the time, and some of the people all the time, but you cannot fool all the people all the time." The Brazilian population understood the meaning of Lincoln's statements well. The next paragraphs will illustrate some of the systemic issues permeating Brazil's economy and how these issues are perpetuating Brazil's low and disappointing economic performance.

\subsection{Low Rates of Economic Growth}

Since 2011, Brazil has grown at lower rates than the large majority of Latin American countries. The country's low level of investments, close to $19 \%$ of Brazil's GDP compared to an average of $23 \%$ for Latin American countries, partially explains Brazil's low growth rates (Baer, 2013; Fraga and Carneiro, 2012, Gouvea, 2013). In 2012, the Brazilian economy only expanded by $0.9 \%$ and in 2013 the expectation was that economic growth rates would be in the $1.5 \%$ range. Brazil needs to grow at least $3 \%$ annually in order to absorb 1.5 million new job seekers annually (De Lorenzo,2013; Lara Rezende, 2013a,c; Salomao and Gerbelli, 2013).

The other major issue facing the Brazilian economy is the low level of productivity of its labor force. Brazil shows a level of productivity that is only about $18 \%$ of the U.S.'s labor force productivity. This has a severe impact on how the Brazilian economy has grown and will continue to grow and develop in the next few years. Issues such as the low level of expenditures on education and technical labor training, the lack of investments in infrastructure, the low levels of investment, and high levels of bureaucracy have been hampering Brazil's efforts towards higher levels of productivity (Bonelli and Bacha, 20913; 
Bonelli and Fontes, 2013; Lima, 2013).

Low levels of investment coupled with low levels of productivity, a business environment that does not promote efficiency, a government that does not promote fiscal austerity but rather heavily taxes Brazil's private sector and does not invest and promote innovation and R\&D in levels needed by the Brazilian economy, imply low rates of growth for Brazil. Brazil's low level of investment in infrastructure, education, innovation and R\&D deeply compromises its ability to expand its GDP potential. The World Bank's "Doing Business 2013 Report" ranks Brazil 130 ${ }^{\text {th }}$ out of 185 countries, showcasing Brazil's cumbersome and non-competitive business environment (The World Bank, 2013). The Heritage Foundation's Index of Economic Freedom also ranks Brazil very low, $100^{\text {th }}$ out of 177 countries, showcasing the strong presence of the state and its intervention in Brazil's economy (Heritage Foundation, 2013).

The formula used in 2008 to jump-start the economy was a combination of public expenditures, increase in bank financing, sectorial incentives and elimination of sectorial taxes. It however has not promoted the expected impact in 2013. Consumption has stagnated adding to the low growth of the Brazilian economy in 2013. Low rates of wage increases, increase levels of debt by Brazil's middle class and raising inflation have cornered Brazil's consumption spree.

Moreover, the Lula-Dilma stress on promoting domestic consumption as a way to promote economic growth was not followed by an increase in domestic production, thus transferred additional demand to imported goods, further aggravating the country's current account deficit and fueling domestic inflation. As a result, it is expected that in the near future the economy will have to slow down, lowering the level of its consumption, as well as the level of real wages, eventually leading to an increase in unemployment. If Brazil sees additional capital flight and lower levels of demand for its commodities, its economy may deteriorate even further in the near future (Goncalves, 2013; Franco, 2013; Lara Rezende, 2013a; The Economist, 2013b).

The increasing deterioration of Brazil's economy was one of the reasons for the "Spring" demonstrations. For instance, the rate of unemployment among Brazilians in the age group 16-24 years old reached $15.3 \%$ in the month of June of 2013, way above Brazil's unemployment rate of $6 \%$. The slow growth of the Brazilian economy is beginning to affect new entrants in the labor force. In the poorest states of Brazil, such as in the Northeast region, the unemployment faced by this age group is even higher in other regions such as $18.5 \%$ in the capital state of Bahia (IBGE, 2013; Spitz and Matsuura, 2013).

In another development, the income of Brazilian's wealthiest 1\% increased more than other income brackets in 2013, widening the country's income inequality. In addition, in one of the poorest regions, the Northeast, income inequality has also increased during the same period (Almeida, 2013). Moreover, the number of workers earning less than minimum wage also increased to 26 million, and $43 \%$ of Brazilian families, or 27 million households, earned less than one minimum wage (Saraiva and Martins, 2013). 


\subsection{Taxes}

In the 1970s, a number of economists used to refer to Brazil as "Belindia" i.e., a country with income inequalities similar to India's, and wealth concentration in some regions of Brazil similar to the ones found in the country of Belgium. In 2013, Brazil is being referred as "Ingana" i.e., tax levels similar to the ones found in England but quality of services similar to the ones found in Ghana (Fraga and Carneiro, Bacha, 2013; Werneck, 2013).

In 2013, the share of taxes in Brazil's GDP was close to $36.2 \%$, comparable to many OECD countries. The share of taxes in Brazil's GDP is also much higher than China's $17 \%$ and India's 18\% respectively (Maia and Cruz, 2013). However, the issue and the reason why we had the Brazilian "Spring" movement is that the large majority of these taxes are not being used for investments, the state is investing less than 7\% of what it collects. The remaining taxes are being spent to run the ever-growing number of ministries and federal employees. The very operation of this enormous state is taking most of the tax revenues (Lara Resezende, 2013a, b).

The economic model sponsored by the Lula-Dilma governments also stressed a large role for the Brazilian state in running and intervening in the economy, further penalizing the state's revenues and crowding-out the private sector (Bonelli and Bacha, 2013). This further distorted the flow of tax revenue towards more important and productive uses. The high levels of taxes also encouraged the expansion of Brazil's underground economy. In 2011, Brazil's underground economy accounted for close to 17\% of Brazil's GDP (FGV, 2012).

\subsection{Number of Ministries}

During the Lula-Dilma administrations the number of ministries expanded from 26 in 2002 to 39 in 2013, costing the country an estimated additional US\$ 29 billion/year to support the expanded administration, or close to half the total amount expected to be invested by the federal government in 2013 (Dame and Alencastro, 2013). The excessive number of ministries did not take any actions or create programs to improve Brazil's security, infrastructure, health care, and urban mobility. There is no economic rationale for this excessive number of ministers; it can only be only explained as part of Lula's "party-coalition government", i.e., political agreements. The increasing disarray becomes clear during the "Spring" when no ministers would come up with government strategies to address the increasing dissatisfaction of Brazil's population (Guzzo, 2013).

It is also close to impossible to orchestrate a nation efficiently and effectively with so many ministers. It is clear that a number of problems permeating Dilma's administration lie inside her government, not outside. This is evidenced by the lack of good management of state revenues, long-term planning, effective strategy to complete major infrastructure projects in a timely manner, and the lack of specific and concrete agenda to curb corruption. Also the Dilma administration's willingness to keep in place Lula's legacy of a coalition government has paralyzed her government, obliging her to comply with allied parties' aggressive pursuit of government staff positions and pork projects (Colon and Monteiro, 2011). 


\subsection{Rising Expectations}

In the past ten years close to 37 million Brazilians were able to ascend from classes D\&E to class C in terms of income (Neri, 2012; Pochmann, 2013). However, this increase in income also resulted in higher levels of expectations for the quality of services that these emerging low-middle-class members were expecting to receive as a result of their increase in tax payments. This new group of consumers has access to the internet and information and demands good public education, health care and security. In addition, they are also pressuring airports and bus terminals to improve, further stressing Brazil's transportation infrastructure. Thus, the government through a number of income transfer programs has dramatically increased the pressure on the country's infrastructure, but did not provide the additional expansion and improvements in the quality of these services. For instance, there still is close to 77 million Brazilians without access to sanitation services (IBGE, 2013). In short, there is an increase in the demand but no corresponding actions were taken on the supply side.

Lula's "New Republic" sold the idea of "all support to social causes", creating a myriad of "social inclusion" income transfer programs, leading to a "Hyperinflation of expectations." As a result, the government's budget, and federal banks have been under pressure to comply with these increasing "social inclusiveness" programs and policies (Franco, 2013). In addition, the Lula and Dilma administrations have created a "client base" of favored groups leading to a distortion in the allocation of resources, favoring those groups closer to the circle of power. The low levels of investment by the federal government close to only $19 \%$ of Brazil's GDP have further undermined the "New Republic" rhetoric. It is also important to note that despite the government's propaganda Brazil is still one of Latin America's countries most affected by income inequality. In the Americas only Guatemala, Honduras and Colombia showed a poorer performance than Brazil (Werneck, 2012; UN, 2012).

The discredit of Brazil's senate and lower house as an effective conduit of Brazilian's demands has further aggravated Brazil's political imbroglio. As a result of the weakening political debate and the Lula-Dilma's administrations ability to co-opt politicians as demonstrated by the "Mensalao" has further incensed Brazil's population. The "coalition party" strategy further compromised the effectiveness of political channels to voice the population's distress with the course the nation has taken, i.e., the channels that would allow them to demand changes no longer represents them.

The weakening of Brazil's democratic process is one of the major factors leading Brazilians to the streets. The protesters were trying to rescue the country's representative "political agenda" frustrated with politicians that are no longer willing to address the public demands.

Additionally, Brazil's senate and the lower house have been transformed in an immense "market of political favors" where benefits are traded and power sharing schemes are designed. This further aggravates Brazilian politicians' ability to become honest brokers.

\subsection{Infrastructure}

In 2013, the PAC program (Growth Acceleration Program), which launched in 2007 under the Lula administration, was running late in delivering a number of very necessary infrastructure 
projects to enhance Brazil's social and economic competitiveness and welfare (Gouvea, 2012; Pereira and Friendlander,2013). Since 2007, only 21 out of the major 42 infrastructure projects have been delivered on time (Pereira, 2013). The perception of Dilma as a good public manager has been shredded by the lack of delivery. Further, the cost of these 42 projects has increased by US\$ 50 billion since 2007. For instance, in 2005 the refinery Abreu e Lima had an initial estimated cost of US\$ 2.8 billion, in 2013 the cost had increased to US\$ 18 billion, and it will be completed in 2015, 4 years behind schedule. This is just one case in dozens of PAC projects that are running behind schedule and have seen its costs increase considerably (Pereira, 2013). In 2012 the government announced a number of new infrastructure projects and a number of new public-private partnerships. However one year later the government had not started any of these announced infrastructure projects (DeLorenzo, 2013; Otta, 2013; Zaparolli, 2013).

The "Instituto Trata Brasil" reports that $65 \%$ of all sewage infrastructure projects in 2013 were paralyzed, delayed, or have not started. Out of the 112 projects under PAC1 only 19 were finalized in the past six years. Out of the 26 projects started under PAC 2, 16 have not even started. An example is the capital of state of Piaui, Teresina, where $83 \%$ of its raw sewage is dumped in the two rivers that cross the city of almost 3.1 million people (Bruno $\mathrm{e}$ Benevides, 2013). For instance, the subway system of the capital of the state of Bahia, Salvador, a 7.5 miles subway line, started construction in 2000, with a 40-month delivery schedule. Thirteen years later, only 3.5 miles have been delivered at a cost three times higher, US\$ 500 million. The lack of governmental agency efficiency and competence has plagued the PAC 1 and PAC 2 programs (Zalis, 2013).

\section{Further Implications}

The "Spring" movement marked an inflection point in Brazil's socio-political movements, one that has not been created and organized by the PT party in the last three decades (Azevedo, 2008; Cabral, 2013b; Pereira, 2010; Secco, 2012). The Labor Party has been at the forefront of public demonstrations for three decades. However, the increasing discredit of its leaders, excessive cases of corruption involving the PT leadership, and the poor management of Brazil's economy further deteriorated and undermined the PTs' ability to effectively act as a conduit and catalyst of changes (Carta, 2013; Delfim Netto, 2013; Lara Resende, 2013a). Moreover, the lack of deliverables that could improve Brazil's quality of life in the dimensions of health care, education, infrastructure and security, culminated in the revolt observed during the month of June across Brazil. The outrageous cost of the 2014 World Cup also revealed the complete disarray and mismanagement of Brazil's tax resources fueling the anger and disappointment of a population that sees promises of a better life being turned into an arrangement of a better life for a select few. The PT excessive expenditures on "political marketing schemes" to over emphasize a fantasy of "efficient managers" fell flat on the face of Brazil's realities (Azevedo, 2008; Pereira, 2010; Rabello, 2013; Sola, 2013).

It was the first time that the Labor Party (PT) faced a massive demonstration on a national scale, and the first time when it was perceived as the villain or the "raison d'etre" for the demonstrations. Since 2002, the PT party became increasingly distant from the population 
and even further from the young segment of Brazil's population and also distant and removed from the new social movements. The Labor Party became increasingly "technocratized" when it left behind its roots, i.e., its initial ideals and support for transformations and for a rupture with the past of Brazilian politics (Nobre, 2013). In 2013, it has become apparent that the PT for the past few years has supported a democracy with low levels of transparency (Nobre, 2013)

The Brazilian "Spring" was an awakening, provoking a drastic change in Brazilian's attitudes towards the state of affairs with the country's political system, politicians, and institutions. The arrival of new entities and new social leaderships caught the Dilma government by surprise (Nossa and Domingos, 2013).

In the past years the Lula and Dilma administrations have implemented an "economic populist" strategy directed at the bottom of Brazil's income pyramid. This strategy has been mostly based on the expansion of the role of the state in Brazil's economy in several dimensions such as: Income transfer programs, minimum wage increases well above productivity increases, government banks extending credit lines below market rates aimed at the expansion of consumption by the low income segments of Brazil's economy, increase in the number of public employees and the increasing financing of government friendly labor unions, social movements, and the state-funding of a selected group of Brazilian private companies (Costa, 2013).

The concept of a "Spring" is not an isolated phenomenon. Brazil's case proves that the manifestation of this type of civil unrest is much more complicated than previously determined. This study served as an institutional review and analysis, providing depth to what we currently understand about the risks produced by one particular "Spring." However, future studies can build upon institutional frameworks to further define what "spring" means, both from a conceptual and quantitative basis. For example, the construction of regression-based hypotheses can build upon the variables proposed through an institutional analysis. In this regard, much work must be done to understand the elusive and complex way that "springs" produce risk in the world political economy.

\section{Final Remarks}

The 2013 "Brazilian Spring" demonstration made apparent the lack of legitimacy and efficacy of many Brazilian institutions. The "Brazilian Spring" was the result of a conjunction of factors and forces that lead to the June demonstrations. The nature of demands by the demonstrators was both a strength and a weakness of "Brazil's Spring" and of other "Springs" around the globe. It is a weakness because they lack objective and concrete proposals to implement these changes, and they are harder to be co-opted by existing political parties. Still, these demands will have to be channeled via a political channel.

It has become clear that Brazil's population has conveyed a very strong message that Brazil's society has matured but its politicians and political system are still in need of an urgent modernization, i.e., Brazil's society is moving at digital speeds and Brazil's political apparatus at an analog speed. Brazil's population is demanding high quality levels of public 
services in the areas of education, public health, security and infrastructure. The Brazilian population no longer accepts to co-exist with a Brazilian government, institutions, and politicians where corruption violates the human rights of Brazil's population on a daily basis. The protesters are also demanding a shift in Brazil's ethical political modus operandi.

\section{References}

Almeida, Alberto (2013). Os Protestos da Melhora. Epoca 789, 58-59.

Almeida, Cassia (2013). Renda do 1\% Mais Rico Cresce Mais que a dos Mais Pobres e Desiqualdade Aumenta. O Globo, 27 de Setembro.

Amaral, Sergio (2013). O Que Disseram as Ruas? O Estado de Sao Paula, 29 de Junho, A2.

Anderson, Lisa (2011). Demystifying the Arab Spring. Foreign Affairs, 90(3), 2-7.

Arantes, Paulo (2013). O Futuro que Passou. O Estado de Sao Paulo, 23 de Junho, E2.

Azevedo, Reinaldo (2008). O Pais dos Petralhas. Rio de Janeiro: Editora Record.

Bacha, Edmar (2013). O Governo Deixou as Coisas Desarranjadas. O Estado de Sao Paulo, 16 de Junho, B4.

Baer, Werner (2013). The Brazilian Economy: Growth and Development. Boulder, CO: Lynne Rienner Publishers.

Bahca, Edmar \& Baugarten, Monica (2013). O Futuro da Inustria no Brasil: Desindustrializacao em Debate. Rio de Janeiro: Editora Civilizacao Brasileira.

Beluzzo, Luis (2013). Ter um Real Forte Uma Hora Vira Encrenca. O Estado de Sao Paulo, 16 de Junho, B4.

Bernabucci, Claudio (2013). A Quem Aproveita o Elefante Branco? Carta Capital. Ano, XVIII(756), 38-39.

Bobbio, Norberto (1987). The Future of Democracy. Minneapolis: University of Minnesota Press.

Bodin, Jean (1955). Six Books of the Commonwealth. Oxford: Alden Press.

Bonelli, Regis \& Bacha Edmar (2013). O Crescimento Brasileiro Revisitado. In Fernando Velos et al. (Eds.), Desenvolvimento Economico: Uma Perspectiva Brasileira (pp. 236-262). Rio de Janeiro: Elsevier Editora.

Bonelli, Regis \& Fontes, J. (2013). Desafios Brasileiros no Longo Prazo. Mimeo. Rio de Janeiro: FGV/EPGE.

Bonin, Robson \& Cabral Otavio (2013). O Ministro Chefe da Oposicao. Veja, edicao 2327, Ano 46, No. 26, 72-76.

Borges, Robinson (2013). A Voz da Rua. Valor, Final de Semana, 21 de Junho, 4-6.

Bruno, Cassio \& Benevides Carolina (2013). PAC do Saneamento Basico em Marcha Lenta. 
O Globo, 19 de Maio, 4.

Buscato, Marcela \& Fillipe, Mauro (2013). O Novo Ativista Digital. Epoca, No. 789.

Cabral, Octavio (2013b). Poder Acuado. Veja, Edicao 2327, Ano 46, No. 26, 66-71.

Cabral, Otavio \& Leitao, Leslie (2013). O Poder na Nuvens. Veja, Edicao 2329, Ano 46, No. 28, 54-59.

Cabral, Otavio (2013a). Dirceu. Rio De Janeiro: Editora Record.

Caldeira, Teresa (2012). Imprinting and Moving Around: New Visibilities and Configurations of Public Space in Sao Paulo. Public Culture, 24(2), 385-419. http://dx.doi.org/10.1215/08992363-1535543

Canetti, Elias (1984). Crowds and Power. New York: Farrar, Straus and Giroux.

Caplan, Brian (2008). The Myth of the Rational Voter: Why Democracies Choose Bad Policies. Princeton: Princeton University Press.

Cardoso, Fernando Henrique (2013). Tempos Dificeis. O Estado de Sao Paulo, 7 de Julho, A2.

Carta, Mino (2013). O PT Ficou para Tras. Carta Capital, Ano XVII, No. 754, 26 de Junho, 20.

Castellar Pinheiro, Armando (2013). Ainda es Manifestacaoes de Junho. Valor, 2 de Agosto, A15.

Castells, Manuel (2012). Networks of Outrage and Hope: Social Movements in the Internet Age. Cambrdige, U.K.: Polity.

Castro, Juliana (2013). Em 25\% das Grandes Cidades. Sequer ha Plano de Transportes. $O$ Globo, 4 de Julho, 4.

Cebela (2013). Mapa da Violencia 2013: Homicidios e Juventude no Brasil. Rio de Janeiro: Centro Brasileiro de Estudos Latino Americanos.

Chaui, Marilena (2013). Uma Nova Classe Trabalhadora. In Emir Sader (Ed.), Lula e Dilma (pp. 123-134). Sao Paulo: Boitempo Editorial.

Colon, Leandro \& Monteiro Tania (2011). Inchaco cria 'Esplanada Oculta' e Gaso de R\$ 100 milhoes por Ano para a Uniao. O Estado de Sao Paulo, 13 de Marco, A4.

Cortes, Don Juan Donoso (2008). Readings in Political Theory. Catholic University of America Press.

Costa, Sergio (2013). O Populismo Economico Ontem e Hoje. O Estado de Sao Paulo, 29 de Junho, B2.

Coutinho, Leonardo (2013). E Pior Ainda. Veja, Edicao 2333, Ano 46, No. 32, 98-108.

Cruz, Patrick (2013). Da Para Vencer a Corrupcao? Exame, Edicao 1045, Ano 47, No. 13, 
24-25.

Dame, Luiza \&Alencastro, Catarina (2013). A Conta do Inchaco. O Globo, 19 de Maio, 3.

De La Boetie, Estienne (1997). The Politics of Obedience. Montreal, Canada: Black Rose Books.

De Lorenzo, Francine (2013). PIB de 2014 pode Ser Menor que o Deste Ano. Valor, 16 de Agosto, A14.

Delfim Netto, Antonio (2013). A Voz da Rua nao e a Vos de Deus new a Voz da Logica. Folha de Sao Paulo, 7 de Julho, B5.

Delfim Netto, Antonio (2013). Priridades Esquecidas. Carta Capital, Ano XVIII, No. 755, 30-31.

Della Porta, Donatella, and Rucht, Dieter (2013). Meeting Democracy. Cambridge: Cambridge University Press. http://dx.doi.org/10.1017/CBO9781139236034

Di Cunto, Raphael (2013). Tarifa de Onibus Sobe Mais que Inflacao. Valor, 18 de Junho, A7.

Doria, Pedro (2013). E Hora de Ler Castells. O Globo, 18 de Junho, 23.

Duarte, Alessandra \& Benevides, Carolina (2013). Onibus sem Licitacao em 13 Capitais. $O$ Globo, 28 de Agosto, 3.

Edelman (2013). Edelman Trust Barometer. Retrieved from www.edelman.com

Ernst \& Young (2013). Infrastructure 2013 - Global Priorities, Global Insights. Washington, D.C.: Ernst \& Young.

Estado de Minas (2013). Mineiro Ligado ao PT e Nomeado Presidente da Funasa. 28 de Abril. Retrieved from www.em.com.br

Faria Mello, Marco (2013). Hora de Fazer uma Correcao de Rumos. Valor, Eu \& Fim de Semana, 5 de Julho, 13.

Faustini, Marcus (2013). Depois Dquilo Tudo que Passou em Junho. O Globo, 6 de Julho, 8.

Fernandes, Maria (2013). Longa Jornada Junho Adentro. Valor, Eu \& Fim de Semana, 9 de Agosto, 4-11.

FGV (2012). Economia Informal Representa 16.8 \& do PIB Brasileiro, diz FGV. Retrieved from www.fgv.com.br

FIESP (2010). Corrupcao: Custos Economicos e Propostas de Combate. Sao Paulo: FIESP.

Fraga, Erica \& Carneiro, Mariana (2012). Brasil e o Que Menos Cresce na America Latina. Folha de Sao Paulo, 18 de Marco, A10.

Fraga, Erica \& Carneiro, Mariana (2013). Erro de Calcula. Folha de Sao Paulo, 23 de Junho, 5. 
Fraga, Erica (2013). Aprendendo a Gastar. Folha de Sao Paulo, 30 de Junho, B8.

Franco, Gustavo (2013). E o Real foi para as Ruas. O Estado de Sao Paulo, 30 de Junho, B4.

Gama, Junia (2013). Um Golpe na Corupcao. O Globo, 27 de Junho, 3.

Gianetti da Fonseca, Eduardo (2013). O Brasileiro tem Espinha Dorsal e Ela nao e Uma Mario-Mole. O Estado de Sao Paulo, 23 de Junho, B8.

Gielow, Igor (2013). Convulsao nas Ruas Sepultou Ideia de que 2014 e Jogo Jogado. Folha de Sao Paulo, 30 de Junho, A8.

Gonclaves, Reinaldo (2013). Deficit de Governanca e Crise de Legitimidade do Estado no Brasil. Retrieved from www.corecon-rj.org.br

Gouvea, Raul \& Montoya, M. J. R, Walsh Steve (2013). How the Corruption Quadruple Helix Affects BRICs. Journal of Politics and Law, 6(2), 1-12. http://dx.doi.org/10.5539/jpl.v6n2p1

Gouvea, Raul (2012). Brazil Post-Lula: Challenges and Opportunities Facing the Brazilian Business Environment. Thunderbird International Business Review, 54(5), 713-727. http://dx.doi.org/10.1002/tie.21495

Gouvea, Raul (2013). Core Issues Facing Brazil's Quest Towards Sustainable Growth. Asian Journal of Latin American Studies, Fall.

Green, James (2000). Brazil in the Aftershock of Neoliberalism. Latin American Perspectives, 27(6), 128.

Guerreiro, Gabriela and Odilla, Fernanda (2013). Virines da Agenda Positiva do Congresso Estao no Papel. Folha de Sao Paulo, 7 de Julho, A7.

Guicciardini, Francesco (1994). Dialogue on the Government of Florence. Cambridge: Cambridge University Press.

Guimaraes, Ligia and Pedroso, Rodrigo (2013). Polemica. Importacao de Medicos seria Saida Parcial. Valor, 31 de Maio, A12.

Guzzi, Drica (2010). We e Participacao - A Democracia no Seculo XXI. Sao Paulo: Editora Senac.

Guzzo, J. (2013). O Fim do Resto. Veja, Edicao 2328, Ano 46, No. 27, 80-82.

Hamid, Shadi (2011). The Rise of the Islamists. Foreign Affairs, 90(3), 40-47.

Heritage Foundation (2013). Economic Freedom Index. Retrieved from www.heritage.org Hotman, Francois (2010). Francogallia. Cambridge: Cambridge University Press.

IBGE (2013). Censo. Rio de Janeiro: IBGE.

Instituto Trata Brasil (2013). Ranking do Saneamento. Retrieved from www.tratabrasil.org 
IPEA (2012). Custo da Violencia Ultrapassa R \$200 bilhoes por ano no Brasil. Rio de Janeiro: IPEA.

Jamshidi, Maryan (2013). The Future of the Arab Spring. Butterworth-Heinemann.

Jenkins, J. Craig (1983). Resource Mobilization Theory and the Study of Social Movements. $\begin{array}{lllll}\text { Annual Review } & \text { of } & \text { Sociology, } & 9, & \text { 527-553. }\end{array}$ http://dx.doi.org/10.1146/annurev.so.09.080183.002523

Jungerfeld, Vanessa (2013). Um Contraste entre os Altos Impostos e o Pouco Retorno. Valor Final de Semana, 21 de Junho, 6.

Juris, Jeffrey (2005). Networked Social Movements: Global Movement for Global Justice. In Manuel Castells (Ed.), The Network Society. Cheltenham, UK: Edward Elgar.

Juris, Jeffrey (2008). Networking Futures. Raleigh/Durham: Duke University Press. http://dx.doi.org/10.1215/9780822389170

Kahne, Joseph, Lee, N., \& Feezell, J. (2013). The Civic and Political of Online Participatory Cultures among Youth Transitioning to Adulthood. Journal of Information Technology and Politics, 10(1). http://dx.doi.org/10.1080/19331681.2012.701109

Kamakura, Wagner \& Mazon, Jose (2013). Estatificacao Socioeconomica e Consumo no Brasil. Sao Paulo: Editora Relativa.

Kramer, Dora (2013). Apropriacao Indebita. O Estado de Sao Paulo, 30 de Junho, A6.

Lago, Miguel \& Orofino, Alessandra (2013). Escutar o Gigante. O Globo, 3 de Julho, 21.

Lara Resende, Andre (2013a). Pojeto do PT Parece do Reime Militar. O Estado de Sao Paulo, 7 de Julho, B6.

Lara Resende, Andre (2013b). O Mal- Estar Contemporaneo. Valor Eu \& Fim de Semana, 5 de Julho, 4-7.

Lara Resende, Andre (2013c). Os Limites do Possivel. Sao Paulo: Portfolio Penguin.

Leal, Luciana (2013). Taxa de Analfabetismo para de Cair e Tem Pequeno Aumento no Brasil. 27 de Setembro. Retrieved from www.estadao.com.br

Leme, Paulo (2013). Brasil Gastou sua Poupanca na Disney. Folha de Sao Paulo, 18 de Agosto, B3.

Lynch, Marc (2013). The Arab Uprising: The Unfinished Revolutions of the New Middle East. New York: Perseus Books.

Machado, Ana (2012). Tropical Sol da Liberdade. Rio de Janeiro: Editora Objetiva.

Machado, Cassiano \& Rocha, Graciliano (2013). Olhem para Paris. Folha de Sao Paulo, Ilustrissima, 23 de Junho, 3.

Machado, Monica (2011). Consumo e Politizacao - Discursos de Poitizacao e Novos 
Engajamentos Juvenis. Rio de Janeiro: Editora Mauad.

Maia, Humberto \& Cruz, Patrick (2013). Choque de Confianca no Pais. Exame, Edicao 1044, Ano 47, No. 12, 49-57.

Manso, Bruno \& Burgarelli, Rodrigo (2013). Epidemia de Manifestacoes Tem Quase 1 Protesto por hora e Atinge 353 Cidades. O Estado de Sao Paulo, 30 de Junho, A10.

Martins, Aricia \& Machado, Tainara (2013). Diagnostico Errado Frustra Retomada da Atividade. Valor, 5 de Agosto, A3.

Martins, Jose (2013). Revolta do Vintem. O Estado de Sao Paulo, 30 de Junho, E3.

Mascaro, Alysson (2013). Aberto para Reforma. O Estado de Sao Paulo, Alias, 30 de Junho, E2.

McVeigh, Rory, Neblett, Carl, \& Shafiq, Sarah (2006). Explaining Social Movement Outcomes: Multiorganizational Fields and Hate Crime Reporting. Mobilization, 11, 23-49.

Mendonca de Barros, Jose (2013). O Governo Perdeu o Rumo. Estado de Sao Paulo, 9 de Junho. Retrieved from www.estadao.com.br

Meyer, David \& Minkoff, Debra (2004). Conceptualizing Political Opportunity. Social Force, 82(4), 1457-1492.

Ming, Celso (2013). Deficit de Credibilidade. O Estado de Sao Paulo, 23 de Junho, B2.

Naim, Moises (2013). The End of Power: From Boardrooms to Battlefields and Churches to States, Why Being in Charge Isn't What it used to be. New York: Basic Books.

Naude, Gabriel (1988). Considerations Politiques Sur Les Coups d'Etat. Hildensheim, Germany: Georg Olms Verlag OG.

Neri, Marcelo (2012). Brasil, um Pais de Classe Media? In Joao Paulo do Reis Vellose (Ed.), Brasil (pp. 27-51). Rio de Janeiro: Jose Olympio Editora.

Nobre, Marcos (2013). Protesto e Resposta a Tecnocracia. Valor, 18 de Junho, A8.

Nogueira, Luis \& Justus, Paulo (2013). O Maestro Desafinado do BNDES. Isto E Dinheiro, Ano 16, No. 823, 36-41.

Nossa, Leonencio \& Domingos, Joao (2013). Ministro amigo de Lula, que faz ponte social fica isolado. O Estado de Sao Paulo, A6.

OECD (2012). Education at a Glance. Paris: OECD.

Oliveira, Eliane (2013). No Soy Loco por ti, Brasil. O Globo, 19 de Maio, 41.

Oliveira, Francisco (2013). Revolucao Sem Rumo Pode dare m Nada, O Que Seria Frustante. Folha de Sao Paulo, 30 de Junho, A14.

Oliveira, Viana (2013). Midia Social e Transformacao Politica. Valor Final de Semana, 21 de Junho, 7. 
Oricchio, Luiz (2013). Brado a Capela. O Estado de Sao Paulo, 23 de Junho, E9.

Ortellado, Pablo (2010). Autonomous Media: Activating Resistance and Dissent. International Journal of Media and Cultural Politics, 6, 125-127. http://dx.doi.org/10.1386/macp.6.1.125/5

Otta, Lu (2013). Plano de Concessao Faz 1 Ano sem Leiloes. O Estado de Sao Paulo, 11 de Agosto, B4.

Papp, Anna \& Rocha, Camilo (2013). Na Internet, Atos Mobilizam 136 Milhoes. O Estado de Sao Paulo, 23 de Junho, A19.

Pereira, Merval (2010). O Lulismo no Poder. Rio de Janeiro: Editora Record.

Pereira, Merval (2013a). Nao Entenderam. O Globo, 4 de Julho, 4.

Pereira, Merval (2013b). O Novo e o Velho. O Globo, 12 de Julho, 4.

Pereira, Merval (2013c). Corrupcao e o Foco. O Globo, 19 de Junho, 4.

Pereira, Renee \& Friedlander, David (2013). Obra da Transnordestina nem Chegou a Metade, mas Orcamento Quase Dobrou. O Estado de Sao Paulo, 26 de Maio, B1.

Pew Research Center. Washington, D.C.: Pew Research Center.

Piketty, Thomas (2010). Wealth Taxation in the $21^{\text {st }}$ Century: A Personal View. Dimensions of Tax Design: The Mirrlees Review. London: Institute for Fiscal Studies, Oxford University Press.

Piketty, Thomas (2013). Estado Bom Muda Sempre. Valor Eu \& Fim de Semana, 19 de Julho, 14-16.

Pilagallo, Oscar (2013). Corrupcao - Entrave ao Desenvolvimento do Brasil. Sao Paulo: Elsevier.

Pochmann, Marcio (2013). Politicas Publicas e Situacao Social na Primeira Decada do Seculo XXI. In Emir Sader (Ed.), Lula e Dilma (pp. 145-156). Sao Paulo: Editora Boitempo.

Pombo, Barbara \& Oliveira, Viana (2013). Promessa e Divida. Valor Eu \& Fim de Semana, 5 de Julho, 8-12.

Pualino, Mauro \& Janoni Alessandro (2013). Inseguranca Economica Aumenta o Impacto Politico dos Protestos. Folha de Sao Paulo, 30 de Junho, A10.

Rabelo, Joao (2013). Uma Dificil Reversao. O Estado de Sao Paulo, 23 de Junho, A8.

Reis Velloso, Joao (2013). Rumo ao Brasil Desenvolvido. In Joao Paulo dos Reis Vellose (Ed.), Rumo ao Brasil Desenvolvido (pp. 3-12). Rio de Janeiro: Editora Campus.

Rheingold, Howard (2002). Smart Mobs: The Next Social Revolution. New York: Basic Books.

Rheingold, Howard (2012). New Smart: How to Thrive Online. MIT Press. 
Ribeiro, Ranato (2013). Como o PT Perdeu a Hegemonia. Valor, 29 de Julho, A6.

Ridente, Marcelo (2013). Que Juventude e Essa? Folha de Sao Paulo, 23 de Junho, A3.

Roche, Sebastian (2006). Le Frisson de L'Emeute: Violences Urbaines et Banlieues. Paris: Seuil.

Romano, Roberto (2013a). Demofobia em Marcha. O Estado de Sao Paulo, 30 de Junho, A1

Romano, Roberto (2013b). Poderes Tiranicos do Brasil. O Estado de Sao Paulo, 17 de Agosto, A2.

Romano, Roberto (2013c). Poderes e Corrupcao. O Estado de Sao Paulo, 23 de Junho, A2.

Rossi, Clovis (2013). Folha de Sao Paulo, 30 de Junho, A22.

Sakate, Marcelo \& Daltro, Ana (2013). O Fim da Bolsa Eike. Veja, Edicao 2329, Ano 46, No. 28, 72-73.

Salomao, Alexa \& Gerbelli, Luiz (2013). Mais um Ano Perdido para o Crescimento da Economia. O Estado de Sao Paulo, 23 de Junho, B4.

Salomao, Alexa (2013). Alto Custo de Energia Electrica Leva Alcoa a Reduzir Producao no Brasil. O Estado de Sao Paulo, 15 de Agosto, B14.

Salvador, Alexandre (2013). Um Chute na Copa. Veja, Edicao 2327, Ano 46, No. 26, 80-81.

Saraiva, Alessandra \& Martins, Diogo (2013). IBGE: Cresce Volume de Trabalhadores que Ganham Menos de um Salario. 27 de Setembro.

Secco, Lincon (2012). Historia do PT. Cotia, Sao Paulo: Atelie Editorial.

Serra, Jose (2013). Para Serra, Saude e Objeto de 'Troca-Troca Politico.' Estado de Sao Paulo, 31 de Julho.

Silva, Cleide (2013). Paises da America Latina Reduzem Compras do Brasil. O Estado de Sao Paulo, 4 de Junho, B3.

Sola, Lourdes (2013). Para Entender o Governo Dilma. O Estado de Sao Paulo, 12 de Junho, A2.

Spitz, Clarice \& Matsuura, Sergio (2013). Jovens na Rua. No olho da Rua. O Globo, 25 de Julho, 19.

Sposito, Maria (2013). Capitalismo e Urbanizacao. Sao Paulo: Editora Contexto.

Sundfeld, Carlos (2013). O Que Falta e Um Estado que Construa o Interesse Publico. $O$ Estado de Sao Paulo, 28 de Julho, A4.

The Economist (2013a). Has the Arab Spring Failed? July 13-19 ${ }^{\text {th }}, 11$.

The Economist (2013b). Grounded - Special Report Brazil, September 28. Retrieved from www.economist.com 


\section{IIMacrothink}

Transparency International (2013). The Corruption Perception Index. Retrieved from www.transparency.org

UN (2012). State of the World's Cities 2012-2013. New York: United Nations.

UN (2013). Human Development Report 2013. New York: United Nations.

UNB (2013). Esudo Mostra que 44\% das Escolas do Pais nao Tem TV ou Computador. www.unb.br.

Valery, Paul (1964). Selected Writings of Paul Valery. New York: New Directions.

Veloso, Tarso (2013). Desembolsos do ‘Bolsa Pescador' vao alcancar R\$ 1.9 bilaho neste Ano. Valor, 19 de Agosto, B13.

Vespa, Bruno (2012). Il Palazzo e La Piazza: Crisi, Consenso e Protesta da Mussolini a Beppe Grillo. Milan, Italy: Mondadori.

Vick, Karl (2013). Street Rule, 182(4), 28-35.

Weber, Demetrio \& Rodrigues, Karine (2013). O Que Fazer com os Royalties? O Globo, 1 de Julho, 8.

Werneck, Felipe (2012). Brasil e 4 Pais Mais Desiqual da America Latina. O Estado de Sao Paulo, 22 de Agosto, C3.

WHO (2011). Global Health Observatory Data Repository.

World Bank (2013). Doing Business 2013. Washington, D.C.: The World Bank.

World Economic Forum (2013). The Global Competitiveness Report. Geneve: World Economic Forum.

Yavetz, Zvi (1988). Plebs and Princeps. Piscataway, NJ: Transaction Publishers.

Zallis, Pieter (2013). Nao Me Engana que Eu nao Gosto. Edicao 2330, Ano 46, No. 29, 52-54.

Zaparolli, Domingos (2013). Lenta Decolagem. Valor - Especial Infraestrutura - Aeroportos, 18 de Junho, F1.

Zucco, Cesar (2013). O Efeito Eleitoral do Bolsa Familia cai a Cada Disputa. O Estado de Sao Paulo, 2 de Junho, A6.

\section{Copyright Disclaimer}

Copyright reserved by the author(s).

This article is an open-access article distributed under the terms and conditions of the Creative Commons Attribution license (http://creativecommons.org/licenses/by/3.0/). 